The new $Z B B$ (if we may coin this abbreviation on the model of the time-honored $Z f B)$ is edited by H. W. Eppelsheimer of Frankfurt, G. Hofmann of Munich, and $\mathrm{H}$. Tiemann of Hamburg. Editorial communications should be addressed to Dr. H. Middendorf at the Bayerische Staatsbibliothek in Munich. The publisher is Vittorio Klostermann of Frankfurt, and four issues per annum carry a subscription price of DM 33.50.

Articles in the first issue are by Eppelsheimer on libraries and documentation and by $F$. A. Schmidt-Künsemüller on planned periodical acquisition by the Deutsche Forschungsgemeinschaft. In the second number
C. Köttelwesch writes on problems of interlibrary loan in Germany, K. Lelbach on the Bonn student library, $H$. Fuchs on the late Hugo Andres Krüss, and Eppelsheimer on the current status of German literary bibliography. In each issue there is a checklist of current bibliographical literature which may well turn out to be comparable in scope and extent to that in the $Z f B$. There are, of course, reviews and news notes.

COLLEGE AND RESEARCH LIBRARIES extends a cordial welcome to the $Z B B$ into the family of library periodicals and wishes it the same distinction attained by the old $Z f B$.Lawrence S. Thompson, University of Kentucky Libraries.

\title{
Communication of Specialized Information
}

The Communication of Specialized Information. Papers Presented before the Seventeenth Annual Conference of the Graduate Library School of the University of Chicago August II-15, 1952. Edited by Margaret E. Egan. Chicago: American Library Association, 1954. 128p. \$4.00.

The Papers Presented before the Seventeenth Annual Conference of the Graduate Library School of the University of Chicago August II-15, 1952, previously published in American Documentation IV, nos. 3 and 4, 1953, are now available in a monograph edited by Margaret E. Egan. Except for a preface by Miss Egan, the content of the papers is identical with their first appearance in $A m e r i-$ can Documentation. The topic of the Conference was the communication of specialized information from which the book takes its title. By this term is meant those research records, articles, essays, and the like which usually appear in near-print format in restricted editions, particularly as to distribution or use, and which take significance because of their timeliness and are especially valuable to subject specialists in technical fields of knowledge. This material, the lifeblood of the highly specialized library, from the traditional library point of view, is considered ephemeral. Other words which have been used to describe this kind of information and its organization are documentation and technical information. The titles of the papers of the participants in the conference which follow, indicate the vast area in com- munications which this type of information encompasses:

"The Problem of Specialized Communication in Modern Society," Verner W. Clapp.

"New Patterns in Scientific Research and Publication," Eugene W. Scott.

"The Distribution-Acquisition Problem in Technical Reporting," Eugene E. Miller.

"Organizing and Servicing Unpublished Reports," Dwight E. Gray.

"Restricted Dissemination of Information and Its Social Implications," Robert Tumbleson.

"Implications for Professional Organization and Training," Mortimer Taube.

"Contemporary Trends in the Production and Use of Social Data," Morris B. Ullman.

"The Use of Social Data by Business, Finance, and Industry," Margaret E. Egan.

"Industrial Relations-A Case Study of Specialized Communication Involving Several Groups," Frederick H. Harbison.

"Emergence of a New Institutional Structure for the Dissemination of Specialized Information," Jesse H. Shera.

As seen at once, the conference posed serious questions for the library profession. The very nature of the material under consideration, its handling and organization, challenges the traditional techniques and practices in use in libraries today. But there is too much here to attempt to analyze in detail. The papers are all worth reading and should become an essential part of professional library literature.

The format of this monograph, however, distributed by the American Library Associa- 
tion for the University of Chicago Graduate Library School, is an unhappy one. The text has been reproduced from typewritten copy by off-set printing, a commendable procedure for small edition publishing; however, in the design of the pages of this book, the long lines and the extensive reduction of the typescript has produced a page which is very difficult to read. For the purposes of this review, it was necessary to go back to the 1953 volume of American Documentation and there, in more readable typescript, study the essays which resulted from the Chicago conference.-John H. Ottemiller, Yale University Library.

\section{Books Received}

The Catholic Booklist, 1955. Edited by Sister Stella Maris. St. Catharine, Kentucky, St. Catharine Col-

$A$ lege, 1955. 69p. 754.6 . DeGolyer Collection in the Check List of the $E$. DeGolyer Collection in the
History of Science and Technology, as of August $I$, 1954. Compiled by Arthur McÁnally and Duane H. D. Roller. Norman, University of Oklahoma Press, I954. I 27p. $\$ 3.00$

The College Handbook and I954-5 Supplement. [New York] College Entrance Examination Board [c.1953] 37 I p.

Development of Public Libraries in Africa: the Ibadan Seminar. Paris, United Nations Educational, Scientific and Cultural Organization, I954. I55p. (Unesco Public Library Manuals, No. 6)

Employee Personnel Practices in Colleges and Univer. sities, I953-54. Champaign, Ill., College and University Personnel Association, I954. I90p. \$4.00.

Index Translationum: International Bibliography of Translations, 5. Paris, United Nations Educational, Scientific and Cultural Organization, 1953. 5 I I p.

$\$ 7.50$.
Indexing Your Book: A Practical Guide for Authors. By Sina Spiker. Madison, University of Wisconsin Press, I954. $28 \mathrm{p}$. $50 \phi$.

The Jews in America, I654-1954; $A$ Checklist of an
Exhibition at the University of Kansas, November 29, 1054, to January 3, I055, celebrating the Tercentenary. Lawrence, 'University of Kansas Library, I955. I 4p.

Libraries and Archives in Sweden. From the Swedish manuscript by Richard Cox. Stockholm, Swedish Institute, 1954. $217 \mathrm{p}$

Public Libraries in France. By James C. McIntosh. Occasional Papers No. 4I. Urbana, University of Illinois Library School, I955. 28p.

School Library Standards, I954. By Nora E Beust. Washington, U.S. Department of Health, Education, and Welfare, I954. Bulletin I954, No. I5. 43p. Southern Literary Culture: A Bibliography of Masters' and Doctors' Theses. By Clyde $\mathrm{H}$. Cantrell and Walton R. Patrick. [University, Ala.] University of Alabama Press, I955. I 2'6p. \$3.00.

Subject Heading Authority List used by the Current List Division, Armed Forces Medical Library. Washington, Government Printing Office, I954. 267p.

Walt Whitman; $A$ Catalog Based upon the Collections of The Library of Congress. Washington, Library of Congress, I955. I 47 p. $65 \%$. Obtainable from Superintendent of Documents, Government Printing Office, Washington 25, D.C.

\section{NEW MONOGRAPHS}

\section{Just published}

LIBRARY COOPERATION IN THE BRITISH ISLES, by Ralph T. Esterquest.

ACRL MONOGRAPH NO. 12 Price 70\&

LIBRARY-INSTRUCTIONAL INTEGRATION ON THE COLLEGE LEV EL. Report of the 40th Conference of Eastern College librarians.

ACRL MONOGRAPH NO. 13 Price $\$ 1.00$

\section{To be published}

THE DEVELOPMENT OF REFERENCE SERVICES IN ACADEMIC RESEARCH LIBRARIES, through interaction of academic traditions, public library practice and special librarianship, by Samuel Rothstein.

ACRL MONOGRAPH NO. 14

Price $\$ 2.75$ (paper); $\$ 3.25$ (cloth)

Order all tifles, whether standing or single orders, including back copies, from:

ACRL MONOGRAPHS

c/o American Library Assn.

50 East Huron Street

Chicago 11, Illinois

\section{WALTER J. JOHNSON, INC.}

\section{Sale and Acquisition of}

- Scientific periodicals: complete sets, short runs, single volumes-all fields, all languages

- Scientific books: out-of-print-domestic, foreign

- Complete subscription service for domestic and foreign periodicals

- All new books of U. S. and foreign publishers

Send requirements and offers to

WALTER J. JOHNSON, INC.

125 East 23 Street, New York 10, N.Y.

Telephone: ORegon 7-6713

Cable address: BOOKJOHNS, N.Y.

Branch offices in London and Frankfurt

Catalogues available on request 